\title{
By Way of a Preface
}

It was coincidence that led me to research and write about the creation of the Rothschild financial dynasty. Just prior to the 2ooth anniversary of the arrival in England in 1798 of Nathan Mayer Rothschild (1777-1836) from the Jewish ghetto in Frankfurt, I arrived at The Rothschild Archive in London in search of sources relating to the long-established mercantile firm of Levy Barent Cohen (1747-1808), who had been London's leading international diamond trader and who happened to be Nathan Rothschild's fatherin-law. Soon after I began my research on Cohen, I was surprised to learn that there were still important questions regarding Nathan that remained unanswered relating to how he made his money and how much he had made. I could not resist the challenge of seeking the answers to those questions.

The challenge was not a simple one. I discovered that, while the history of the Rothschilds has been a well-plowed field, it has not been plowed well. All accounts, including the most recent and the most notable, contain errors of fact and repeated myths, for example, that Nathan Rothschild profited from receiving early news of Napoleon's defeat at Waterloo. I was persuaded that a study based on extant contemporary sources should be written to explain when and how Nathan unexpectedly catapulted into the leadership of Europe's merchant-banking elite, and how, within a generation, Nathan and his four brothers created a financial dynasty the likes of which were unknown in modern times.

For many years, these questions could not possibly have been answered authoritatively. I was reminded of this by David S. Landes, Harvard University Professor Emeritus of History and Economics, when he presented the Inaugural Rothschild Archive Lecture on 30 May 2000. ${ }^{1}$ Landes quoted Joseph Wechsberg's declarative statement from his 1966 book The Merchant Bankers: 
"The Rothschild legend has long ago outrun the facts. This is the Rothschilds' own fault. They are even more reticent and aloof than other merchant bankers when family matters are concerned. They developed the technique of absolute discretion to perfection. Their family labyrinths are complex. . . . Significantly, no Rothschild-approved history of the family has yet appeared. A whole library of books exists about the Rothschilds. All were written without their blessing, often against their wishes, mostly without their co-operation, and sometimes they have protested in court against them.

No one has ever gone through all the family archives. Perhaps once a Rothschild will be permitted but certainly not an outsider. The family has produced many diversified talents in the past two hundred years. Someday there will be a historian named Rothschild and he will write the book." 2

In 1982, Lord Rothschild published The Shadow of a Great Man ${ }^{3}$ but it is not what Wechsberg had in mind in 1966. The Shadow of a Great Man has merit but it is not a full-length study based on an exhaustive investigation of the Rothschild archival manuscripts.

The book that I have written is such a study. But it is not a biography of Nathan Rothschild nor is it a history of the Rothschild family. The available contemporary sources simply do not contain the kind of information that would make those possible. The details for which are almost wholly absent from the multivolume collections of archival sources at The Rothschild Archive and The British Library Manuscripts Collections, two repositories central to this study. Nathan left no philosophical tracts, diaries, memoirs, or other writings that would have provided insight into his character or personality. The bulk of the manuscripts above his name concern his business transactions and reveal that he was a tough negotiator. His autograph appears rarely. John Charles Herries, the British Commissary-in-Chief, who met with him almost daily from I8I4 to I8I6, rarely remarked about Nathan the man. The richest source for understanding Nathan's personality and character remains the family correspondence which, while primarily focusing on business transactions, is laced with personal commentary and acrimonious exchanges.

This study is a narrative that traces the development of Nathan's early career as merchant, arbitrager, and banker and how he and his brothers exploited circumstance and opportunity during the Napoleonic wars. Subsequently, they created one of the more extraordinarily wealthy and powerful financial institutions in the world during the nineteenth century.

Many of the archival sources used for this study have never before been researched. The greatest number of these are deposited in three archives: 
The Rothschild Archive in London [RAL], The Public Record Office at Kew Gardens [PRO], and The British Library in London [BL]. Additional essential sources are in the Hope \& Co. collection at the Gemeentearchief, Amsterdam [GAA], in The Wellington Papers at the University of Southampton Library, Southampton, UK [WP], in the Northbrook Papers at the Baring Archive, ING Group NV, London, and the Public Record Office, The Family Records Centre, London [PROB].

The manuscripts in The Rothschild Archive in London comprise several different categories of value for this study but the correspondence of the five Rothschild brothers is indispensable. The Rothschilds wrote in several languages: English, French, German, and Judendeutsch, which was the spoken German of Frankfurt during the first two decades of the nineteenth century and which was written in Hebrew script. Judendeutsch is one of the more difficult languages to translate into intelligible English, not only because the original letters are devoid of punctuation but also because their authors presumably wrote in as unsophisticated a manner as they spoke. Following the Second World War, a team of "translators" undertook to summarize into English a voluminous number of the Judendeutsch correspondence, which now comprises the T-files at RAL, but these translations are untrustworthy. About fifteen years ago, the archival administration undertook to translate anew these letters in a team-organized project that still is in progress. Each of the Judendeutsch letters is translated into oral German and taped, and that tape is subsequently transcribed into a German text and translated into English. I have used this set of Judendeutsch letters as translated into English. From time to time, I have consulted Mr. Mordichae Zucker and Dr. Rainer Liedtke (members of the translation team) about letters I have considered problematic and I have acknowledged their assistance in notes. Nevertheless, I am solely responsible for use of the Judendeutsch letters in English translation.

The multivolume collection of the John Charles Herries Papers at the British Library [HP] was as indispensable for this study as the manuscripts at RAL. As Commissary-in-Chief, Herries not only held an extraordinarily important position in the British government and was charged with supplying money to the British Military Chest on the Continent and paying subsidies to British allies who fought against Napoleon, but he also was the only British official who supervised and met with Nathan Rothschild almost daily for the purpose of executing these responsibilities. From time to time, Herries corresponded with Nathan's brothers and worked with them when 
he visited Amsterdam, Frankfurt, and Paris. Moreover, while RAL contains many important manuscripts and accounts associated directly or indirectly with Herries, the Herries Papers contain several volumes of manuscripts and accounts associated directly or indirectly with Nathan Rothschild and his brothers.

The archives of The Royal Mint are currently deposited at the PRO and they contain information relating to the British government's minting of foreign gold coins-namely, the Hanoverian George d'Or and the French Louis d'Or, which Herries and the Rothschilds deposited into the Military Chest and also used to pay subsidies to Great Britain's allies. These sources and those at the BL and RAL are crucial to an understanding of how the Royal Mint was used to effect British policy during the later years of the war against Napoleon.

The multibox collection of Treasury Papers at the PRO provide a detailed contemporary account of the Treasury's responsibilities and actions regarding money flows into the Military Chest and subsidies paid to Great Britain's allies. It contains numerous communications to and from Nathan Rothschild, John Charles Herries, and Commissary Generals. However, it is a difficult collection to work with because the materials are not catalogued in a straightforward manner. The reports and correspondence addressing a particular affair of state are clustered together, with each report or correspondence folded one into the other and with the business of each sometimes covering a period of several years. The only way to research these papers effectively is to go through each piece in every box from the later months of I8I3 through March I8I6.

\section{Notes}

I. "Research Is the Art of Encounter: The Sources of Business History," The Rothschild Archive. Review of the Year April I9g9-March 2000 (London: The Rothschild Archive Trust), p. 7.

2. Ibid., citing Wechsberg, Joseph. The Merchant Bankers (paperback ed.). New York: Pocket Books, by arrangement with Little, Brown, pp. 263-64.

3. London: New Court, St. Swithin's Lane. 